\title{
Auricular Artery
}

National Cancer Institute

\section{Source}

National Cancer Institute. Auricular Artery. NCI Thesaurus. Code C52849.

An artery that supplies oxygenated blood to the ear. 